\title{
Paeonol exerts potential activities to inhibit the growth, migration and invasion of human gastric cancer BGC823 cells via downregulating MMP-2 and MMP-9
}

\author{
ZHONG-KUAN LYU ${ }^{1 *}$, CHANG-LING LI $^{1 *}$, YAN JIN $^{2 *}$, YU-ZHAO LIU $^{3}, \mathrm{XI} \mathrm{ZHANG}^{3}$, FANG ZHANG $^{2}$, \\ LU-NING NING ${ }^{2}$, ER-SHUN LIANG ${ }^{4}$, MIN MA $^{1}$, WEI GAO ${ }^{1}$, MING-XIANG ZHANG $^{4}$ and DE-SHAN LIU ${ }^{1}$ \\ ${ }^{1}$ Department of Traditional Chinese Medicine, Qilu Hospital of Shandong University, Jinan, \\ Shandong 250012; ${ }^{2}$ Shandong University of Traditional Chinese Medicine, Jinan, Shandong 250355; \\ ${ }^{3}$ Shandong University School of Medicine; ${ }^{4}$ Key Laboratory of Cardiovascular Remodeling and Function \\ Research, Qilu Hospital of Shandong University, Jinan, Shandong 250012, P.R. China
}

Received October 9, 2016; Accepted July 24, 2017

DOI: $10.3892 / \mathrm{mmr} .2017 .7576$

\begin{abstract}
Paeonol (Pae) is an herbal extract that has attracted extensive attention for its anti-cancer effects demonstrated by a number of studies, which have predominantly demonstrated inhibition of cell proliferation and induction of apoptosis. The influence of Pae on cancer cell metastasis has been less widely reported. The present study aimed to investigate the under-reported effects of Pae on the growth, invasion and migration of poorly differentiated BGC823 gastric cancer cells with strong invasive and metastatic abilities. The anti-proliferative and pro-apoptotic effects of Pae on BGC823 cells were verified by Cell Counting kit-8 and Annexin V-fluorescein isothiocyanate/propidium iodide assays. Cell scratch-wound healing and Transwell methods were applied, and it was demonstrated that Pae could exert inhibitory activities on the invasion and migration of BGC823 cells. Furthermore, it was indicated by western blot analysis that Pae could downregulate the protein expression levels of matrix metalloproteinase (MMP)-2 and -9 in a concentration-dependent manner, which may support a novel potential mechanism accounting for its anti-cancer effects on gastric cancer.
\end{abstract}

\section{Introduction}

Gastric cancer is one of the most common types of malignant tumors worldwide (1). According to the data recently issued by

Correspondence to: Professor De-Shan Liu, Department of Traditional Chinese Medicine, Qilu Hospital of Shandong University, 107 Wenhua Xi Road, Jinan, Shandong 250012, P.R. China

E-mail: liudeshan@sdu.edu.cn

*Contributed equally

Key words: paeonol, gastric cancer, BGC823 cells, migration, invasion, matrix metalloproteinase-2, matrix metalloproteinase- 9
World Health Organization International Agency for Research on Cancer, gastric cancer is still a serious health threat in many parts of the world, especially in some Asian countries, such as China, due to high incidence and low early detection rates (2-4). Due to symptomatic delay, many gastric cancer cases have developed into advanced stage with obvious invasion and migration of cancer cells by the time of diagnosis (5).

Degradation of extracellular matrix (ECM) is recognized to be a key step in the complex processes of invasion and migration of cancer cells $(6,7)$. Many studies have demonstrated that matrix metaloproteinases (MMPs), a large family of proteolytic enzymes, serve an important role in resolving constituents of the ECM (8-10). MMP-2 and MMP-9 are proven to act as chief members in the family for their special abilities to degrade type IV collagen, the major component of basement membrane in ECM (11-13). It has been verified that the metastasis of various malignant tumors, including gastric cancer, are associated with an increase in MMP-2 and MMP-9 expression levels (14-17). Thus, expression levels of MMP-2 and MMP-9 are often used as important markers to evaluate the invasion and migration of cancer cells (18-20).

Paeonol (Pae, 2-hydroxy-4-methoxyacetophenone) is the principal bioactive component in the root bark of Paeonia suffruticosa Andr. (Ranunculaceae) and the root of Cynanchum paniculatum (Bunge) K. Schum, which are herbal medicines widely used in China $(21,22)$. A number of studies have demonstrated that Pae has inhibitory effects, including inhibition of cell proliferation and induction of apoptosis, on various malignant tumors (23-26). Anti-metastatic activities of Pae on human fibrosarcoma and chondrosarcoma cells have been reported $(27,28)$. Therefore, Pae may exert anti-metastatic activities in highly metastatic gastric cancer. Therefore, the present study aimed to investigate the effects of Pae on the growth, invasion and migration of poorly differentiated BGC823 gastric cancer cells with strong invasive and metastatic abilities.

In the present study, the anti-proliferative and pro-apoptotic effects of Pae on BGC823 cells were verified; it was also demonstrated that Pae could inhibit the invasion and migration 
of BGC823 cells. Furthermore, the expression levels of MMP-2 and MMP-9 were assessed, and their dose-dependent downregulation by Pae may be one of the potential mechanisms responsible for the promising anti-cancer effects of Pae.

\section{Materials and methods}

Materials. Pae (solid, $20 \mathrm{mg} /$ bottle, purity $>98 \%$ by high performance liquid chromatography) was obtained from Dalian Meilun Biotechnology Co., Ltd. (Dalian, China; cat. no. MB1762-S). The BGC823 human gastric cancer cell line was obtained from CHI Scientific, Inc. (Jiangyin, China). RPMI-1640 medium and fetal bovine serum (FBS) were purchased from Hyclone; GE Healthcare Life Sciences (Logan, UT, USA). A Cell Counting kit-8 (CCK-8) was purchased from Beyotime Institute of Biotechnology (Shanghai, China). An Annexin V-fluorescein isothiocyanate/propidium iodine (FITC/PI) apoptosis detection kit was obtained from BD Biosciences (San Jose, CA, USA). Cell lysis buffer, antibiotic (penicillin and streptomycin) solution and dimethyl sulfoxide (DMSO) were from Beijing Solarbio Science \& Technology Co., Ltd. (Beijing, China). A Transwell chamber and Matrigel were from Corning Incorporated (Corning, NY, USA). An Enhanced Chemiluminescence (ECL) kit was from EMD Millipore (Billerica, MA, USA). A $\beta$-actin antibody, and horseradish peroxidase-labeled goat anti-mouse and anti-rabbit secondary antibodies (cat. nos. TA-09, ZB-2305 and ZB-2301 respectively) were from Beijing Zhongshan Golden Bridge Biotechnology Co., Ltd. (Beijing, China). MMP-2 (cat. no. YT2798) and MMP-9 (cat. no. YT1892) antibodies were from ImmunoWay Biotechnology Company (Plano, TX, USA).

Cell culture and preparation of Pae solution. BGC823 human gastric cancer cells were routinely cultured in RPMI-1640 medium supplemented with $10 \% \mathrm{FBS}, 100 \mathrm{U} / \mathrm{ml}$ penicillin and $100 \mu \mathrm{g} / \mathrm{ml}$ streptomycin, in a humidified incubator $\left(37^{\circ} \mathrm{C}\right.$, $5 \% \mathrm{CO}_{2}$ ). DMSO was used as a solvent to dissolve Pae in serial concentrations $(0.05,0.1,0.2,0.4,0.6$ and $0.8 \mathrm{mg} / \mu \mathrm{l})$. Corresponding concentrations of Pae in culture solution ( 0.05 , $0.1,0.2,0.4,0.6$ and $0.8 \mathrm{mg} / \mathrm{ml}$ ) were obtained for experiments by mixing $1 \mu \mathrm{l}$ Pae/DMSO solution into $1 \mathrm{ml}$ culture solution.

CCK- 8 assay. Cell viability was detected by CCK-8 assay. First, BGC823 cells were seeded into 96-well plates (200 $\mu 1$, $5 \times 10^{3}$ cells/well). During logarithmic cell growth, the medium was replaced with fresh medium containing Pae of serial concentrations $(0,0.05,0.1,0.2,0.4,0.6$ and $0.8 \mathrm{mg} / \mathrm{ml})$. Three wells were set for each concentration group. Culture medium containing equivalent DMSO without Pae was applied in control wells. CCK-8 reagent $(10 \mu \mathrm{l})$ was added into each well under protection from light at 24 and $48 \mathrm{~h}$ of treatment. After $4 \mathrm{~h}$, the absorbance (A) was measured at a wavelength of $490 \mathrm{~nm}$ using a microplate autoreader (Bio-Rad Laboratories, Inc., Hercules, CA, USA). The formula for calculation of relative inhibition rate (RIR) was as follows: RIR $(\%)=$ (the mean A value of control group-the mean A value of each concentration Pae group) / the mean A value of control group x $100 \%$.

Based on the results of the CCK-8 assay, BGC823 cells were divided into four groups for subsequent experiments: Control group without Pae $(0 \mathrm{mg} / \mathrm{ml})$, low concentration Pae
(LP, $0.1 \mathrm{mg} / \mathrm{ml}$ ) group, moderate concentration Pae (MP, $0.2 \mathrm{mg} / \mathrm{ml}$ ) group and high concentration Pae (HP, $0.4 \mathrm{mg} / \mathrm{ml}$ ) group.

Apoptosis analysis by flow cytometry. An Annexin V-FITC/PI assay was used to examine cell apoptosis of the four groups. BGC823 cells were seeded into 6 -well plates $(2 \mathrm{ml}$, $0.5 \times 10^{5}$ cells/well) and treated with the corresponding concentration of Pae (0, 0.1, 0.2 and $0.4 \mathrm{mg} / \mathrm{ml})$. After $24 \mathrm{~h}$, cells in each group were harvested with $0.25 \%$ trypsin (Gibco; Thermo Fisher Scientific, Inc., Waltham, MA, USA), washed in cold phosphate-buffered saline (PBS) and centrifuged at $168 \mathrm{x} \mathrm{g}$ and at $4^{\circ} \mathrm{C}$ for $3 \mathrm{~min}$. The supernatant was removed and the cells were resuspended with $400 \mathrm{ml}$ binding buffer from BD Biosciences (San Jose, CA, USA), containing 0.1 M Hepes/ $\mathrm{NaOH}$ (pH 7.4), $1.4 \mathrm{M} \mathrm{NaCl}$ and $25 \mu \mathrm{M} \mathrm{CaCl}_{2}$. Subsequently, $5 \mu 1$ AnnexinV-FITC and $5 \mu \mathrm{l}$ PI were added and mixed gently with the resuspended cells in the dark at room temperature. After a 15-min incubation, cell apoptosis was detected within $1 \mathrm{~h}$ of staining by flow cytometry (BD Biosciences). Apoptosis data was analyzed using FlowJo software version 7.6 (FlowJo LLC., Ashland, OR, USA).

Cell scratch-wound healing assay. BGC823 cells were cultured in 6-well plates. Once cells had grown to 70-80\% confluence as a monolayer, the monolayer was scratched in a straight line using $200 \mu \mathrm{l}$ pipette tips along the bottom middle of the well to establish wound areas. Subsequently, the original culture solution was discarded, and the cells were washed gently twice with PBS. Subsequently, BGC823 cells in each group were cultured in new medium containing the corresponding concentration of Pae. At the set treatment time points $(0,24$ and $48 \mathrm{~h})$, cell wound areas were imaged under an inverted optical microscope (Olympus Corporation, Tokyo, Japan). The width of the cell wound was measured by Photoshop CS5 software version 12.0.2 (Adobe Systems Europe, Ltd., Maidenhead, UK). Healing rate (HR) was calculated as follows: HR $(\%)=$ (width of wound at $0 \mathrm{~h}$ - width of wound at 24 or $48 \mathrm{~h}$ ) / width of wound at $0 \mathrm{~h} \mathrm{x} 100 \%$.

Invasion assay. Transwell invasion assay was performed to determine cell invasion. BGC823 cells grown by routine culture were harvested and resuspended with culture solution containing the appropriate concentration of Pae for each group. RPMI-1640 medium supplemented with 20\% FBS (500 $\mu$ l) was added in advance into Transwell lower chambers in a 24-well plate. Following this, the resuspended BGC823 cells were seeded onto the artificial basement membrane (Matrigel) in Transwell upper chambers with $8 \mu \mathrm{m}$ pores, and incubated for $24 \mathrm{~h}$. Cells which had passed through the artificial basement membrane were fixed with $4 \%$ paraformaldehyde for $30 \mathrm{~min}$, stained with crystal violet for $20 \mathrm{~min}$ at room temperature and air-dried. Meanwhile, the cells on the upside of the artificial basement membrane were cleared out. Subsequently, the stained cells were imaged under an inverted optical microscope. The numbers of stained cells were measured in three different randomly selected fields.

Western blot analysis. The expression levels of MMP-2 and MMP-9 were detected by western blotting. Briefly, 
BGC823 cells of each treatment group were incubated for $48 \mathrm{~h}$ with exposure to corresponding concentrations of Pae. Subsequently, the culture solution was removed, cells were washed twice with PBS, lysed with an ice-cold mixture of lysis buffer and protease inhibitors, and centrifuged for $15 \mathrm{~min}$ at $19,700 \mathrm{xg}$ at $4^{\circ} \mathrm{C}$. The protein concentrations in the collected supernatant was determined using a Bicinchoninic Acid kit, and then the protein lysates were mixed with loading buffer and heated for $10 \mathrm{~min}$ at $98^{\circ} \mathrm{C}$. Sodium dodecyl sulfate (SDS)-polyacrylamide gel (8\% separating gel and 5\% stacking gel) electrophoresis (PAGE) was used to separate the proteins, and $10 \mu \mathrm{l}$ of each protein sample was loaded onto the corresponding lane of the gel. Following separation by SDS-PAGE, the proteins were transferred to a polyvinylidene fluoride membrane and blocked in a mixture of Tris-buffered saline with Tween-20 (TBST) with non-fat milk $(50 \mathrm{mg} / \mathrm{ml})$ for $1.5 \mathrm{~h}$ at room temperature. After being washed with TBST, the membranes were incubated at $4^{\circ} \mathrm{C}$ for $16 \mathrm{~h}$ with appropriate primary antibodies (1:1,000 dilution for MMP-2, MMP-9 and $\beta$-actin). Subsequently, the membranes were taken out, washed with TBST and incubated at room temperature for $1.5 \mathrm{~h}$ with the appropriate secondary antibody (1:5,000 dilutions for both anti-mouse and anti-rabbit). After being washed with TBST, the protein bands on the membranes were visualized using an ECL kit, processed by Image Lab Software 5.1 (Bio-Rad Laboratories, Inc.) and quantified by Image $\mathrm{J}$ software version 1.46r (National Institutes of Health, Bethesda, MD, USA).

Statistical analysis. Data were analyzed using SPSS 20.0 software (IBM Corp., Armonk, NY, USA). All data are presented as the mean \pm standard deviation. One-way analysis of variance and Student's t-tests were used to analyze statistical data. The post hoc test was performed using Tukey's method in conjunction with the analysis of variance to find means that were significantly different from each other. $\mathrm{P}<0.05$ was considered to indicate statistically significant difference.

\section{Results}

Inhibitory effect of Pae on the proliferation of BGC823 cells. To verify the inhibitory effect of Pae on the proliferation of gastric cancer cells, CCK- 8 assays were used. The results (Fig. 1) demonstrated that at the 24 and $48 \mathrm{~h}$ time points, inhibitory rates of Pae on BGC 823 cells increased gradually with the rise of concentration $(0,0.05,0.1,0.2,0.4,0.6$ and $0.8 \mathrm{mg} / \mathrm{ml}$ ). When the concentration of Pae was $0.4 \mathrm{mg} / \mathrm{ml}$, the 24 and $48 \mathrm{~h}$ inhibitory rates were $(53.3 \pm 2.1)$ and $(56.1 \pm 2.4) \%$, respectively. However, when the concentration reached $0.6 \mathrm{mg} / \mathrm{ml}$, the 24 and $48 \mathrm{~h}$ inhibitory rates were $(68.3 \pm 1.6)$ and $(80.1 \pm 6.0) \%$, respectively, revealing obvious cytotoxicity. According to the results of CCK- 8 assays, low, moderate and high concentrations of Pae were established as 0.1, 0.2 and $0.4 \mathrm{mg} / \mathrm{ml}$, respectively.

Cell morphological observation. Observed under an optical microscope after $24 \mathrm{~h}$ of treatment (Fig. 2), BGC823 cells in the control group exhibited a clear shape and orderly arrangement. However, compared with the control group, the LP, MP and HP groups demonstrated obvious morphological changes.

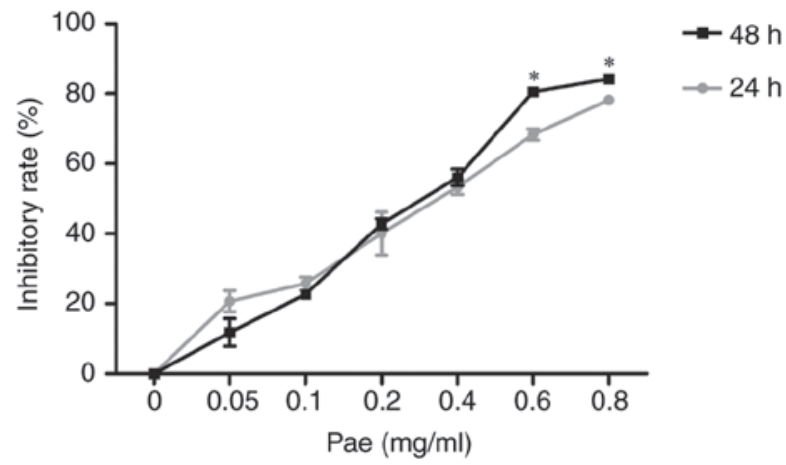

Figure 1. Inhibitory effect of Pae on the proliferation of BGC823 after 24 and $48 \mathrm{~h}$ of treatment. Data are expressed as the mean \pm standard deviation $(n=3)$. ${ }^{*} \mathrm{P}<0.05$ vs. same Pae concentration group at 24 h. Pae, paeonol. $n$, the number of independent experiments performed.

Furthermore, the HP group altered the most obviously with an unclear shape, disorderly arrangement, fewer cells and more cell death.

Pae induces apoptosis of BGC823 cells. The pro-apototic effect of Pae on BGC823 cells was verified using an AnnexinV-FITC/PI assay. The results demonstrated that cell apoptosis rates of the LP, MP and HP groups, (12.7 \pm 2.2$)$, $(15.1 \pm 2.0)$ and $(18.3 \pm 1.7) \%$, respectively, increased in a significant concentration-dependent effect and were markedly higher compared with the control group $(\mathrm{P}<0.05$ or $\mathrm{P}<0.01$; Fig. 3).

Effects of Pae on the migration and invasion of BGC823 cells. To explore the effects of Pae on migration and invasion of gastric cancer cells, the cell scratch-wound healing and Transwell methods were applied, respectively. As presented in Fig. 4, the $24 \mathrm{~h}$ wound healing rates of the LP, MP and HP groups were $(27.3 \pm 5.1),(19.3 \pm 2.9)$ and $(14.7 \pm 7.3) \%$, and the $48 \mathrm{~h}$ wound healing rates were $(36.5 \pm 4.6),(29.3 \pm 6.0)$ and $(17.7 \pm 3.1) \%$, respectively, which were markedly reduced

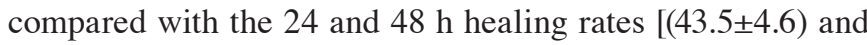
$(62.5 \pm 5.0) \%$ ] of the control group $(\mathrm{P}<0.05$ or $\mathrm{P}<0.01)$.

The Transwell invasion assay demonstrated that the cell numbers passing the artificial basement membrane in the LP, MP and HP groups (118 $\pm 17,76 \pm 9,42 \pm 7$ and, respectively) were significantly reduced compared with the number of invading cells $(332 \pm 16)$ observed in the control group $(\mathrm{P}<0.01$; Fig. 5). Together, the cell scratch-wound healing and Transwell assays demonstrated that Pae could inhibit the migration and invasion of BGC823 cells with a significant concentration-dependent effect.

Pae downregulated the expression levels of MMP-2 and $M M P-9$ in BGC823 cells. In order to further investigate possible mechanisms of the inhibitory effects of Pae on the migration and invasion of gastric cancer cells, the expression levels of MMP-2 and MMP-9 in BGC823 cells were detected by western blotting. The results demonstrated that the expression levels of MMP-2 and MMP-9 in BGC823 cells of the LP, MP and HP groups were significantly reduced compared with the control group (Fig. 6). Furthermore, with 


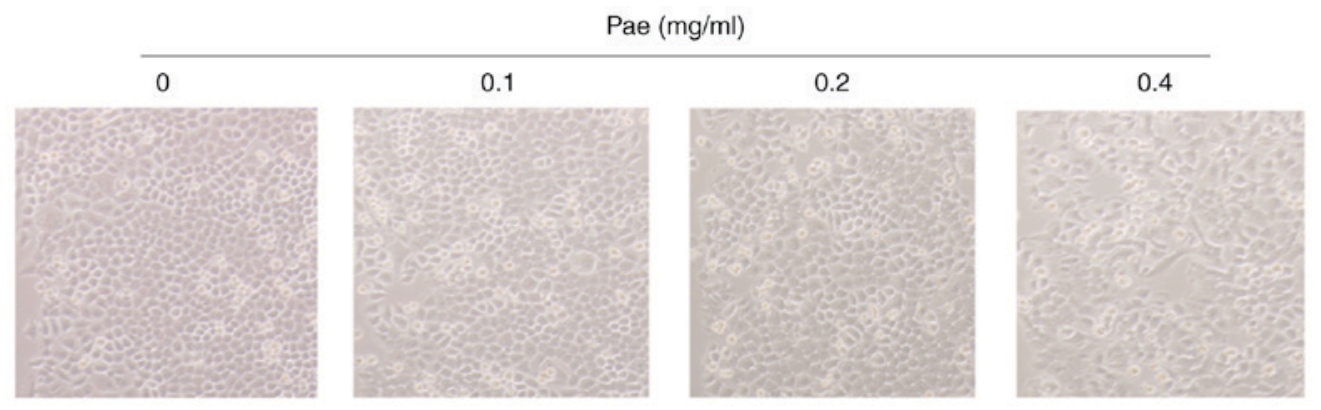

Figure 2. Cell morphological observation in each group under an inverted optical microscope at the $24 \mathrm{~h}$ of treatment (magnification, $\mathrm{x} 200)$. Pae $0 \mathrm{mg} / \mathrm{ml}$, control group; $0.1 \mathrm{mg} / \mathrm{ml}$, low concentration Pae group; $0.2 \mathrm{mg} / \mathrm{ml}$, moderate concentration Pae group; $0.4 \mathrm{mg} / \mathrm{ml}$, high concentration Pae group. Pae, paeonol.

A
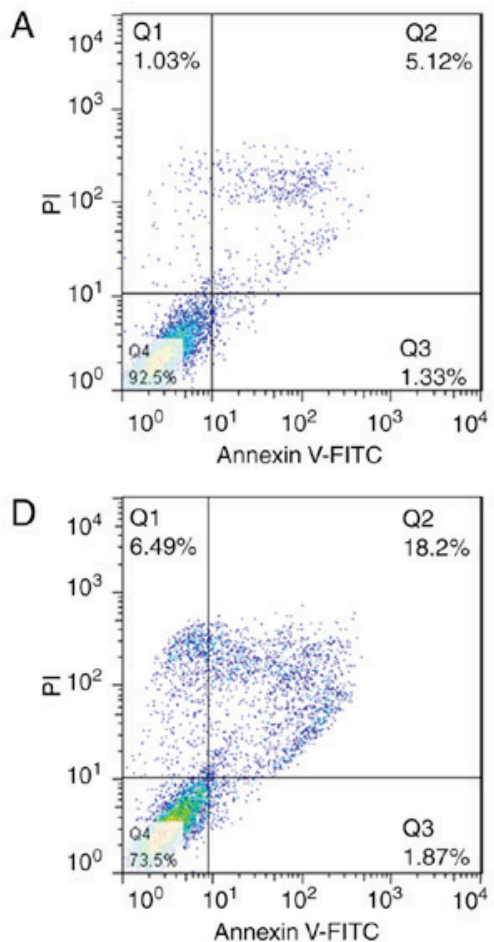

B
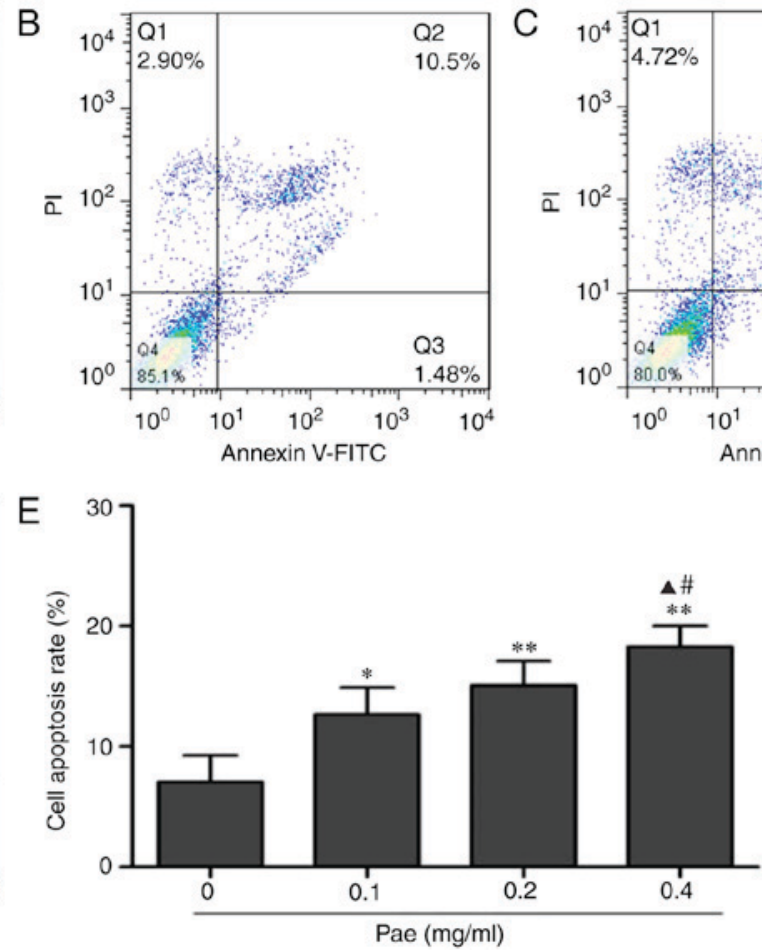

Figure 3. Effect of Pae on the apoptosis of BGC823 cells. Cell apoptosis data were analyzed in each group after $48 \mathrm{~h}$ treatment with corresponding concentration of Pae at (A) $0 \mathrm{mg} / \mathrm{ml}$, (B) $0.1 \mathrm{mg} / \mathrm{ml}$, (C) $0.2 \mathrm{mg} / \mathrm{ml}$ and (D) $0.4 \mathrm{mg} / \mathrm{ml}$. (E) Quantitative comparison of the apoptosis rates among groups. Data are expressed as the mean \pm standard deviation $(\mathrm{n}=4) .{ }^{*} \mathrm{P}<0.05,{ }^{* *} \mathrm{P}<0.01$ vs. $0 ;{ }^{\mathbf{\Delta}} \mathrm{P}<0.05$ vs. $0.1 ;{ }^{*} \mathrm{P}<0.05$ vs. 0.2 . Pae 0 mg/ml, control group; $0.1 \mathrm{mg} / \mathrm{ml}, \mathrm{low}$ concentration $\mathrm{Pae}$ group; $0.2 \mathrm{mg} / \mathrm{ml}$, moderate concentration Pae group; $0.4 \mathrm{mg} / \mathrm{ml}$, high concentration Pae group. FITC, fluorescein isothiocyanate; PI, propidium iodide; Pae, paeonol. $\mathrm{n}$, the number of independent experiments performed.

the concentration increase of Pae from $0-0.4 \mathrm{mg} / \mathrm{ml}$, the expression levels of MMP-2 and MMP-9 demonstrated a gradual concentration-dependent decrease $(\mathrm{P}<0.05$ or $\mathrm{P}<0.01)$. Thus, the mechanism that Pae exerts an inhibitory effect the migration and invasion of BGC823 cells may, at least in part, be attributable to the downregulation of MMP-2 and MMP-9 protein expression.

\section{Discussion}

Pae is a natural product, with a white needle crystal structure and melting point of $51-52^{\circ} \mathrm{C}$ that is extracted from the root bark of Paeonia suffruticosa and the root of Cynanchum paniculatum, and is widely used in traditional Chinese medicine (TCM) $(22,29)$. Medicinally, Pae is extensively implemented for its various pharmacological and physiological effects such as analgesia, antipyresis, sedation, immunoregulation, anti-inflammation and tumor suppression (30,31). In clinical TCM anti-tumor treatment, Cynanchum paniculatum is usually prescribed for pain reduction. Our previous clinical observations indicated that the recipes with Cynanchum paniculatum could improve chemotherapy effects of gastric cancer patients at advanced stages of disease progression. Furthermore, Pae, the major bioactive component of Cynanchum paniculatum, was previously reported to enhance apoptotic induction effect of cisplatin on human hepatoma cells and reverse paclitaxel resistance in human breast cancer cells $(32,33)$.

The anti-cancer effects of Pae with respect to proliferation inhibition and apoptosis induction on cancer cells are well established in the scientific literature. However, the effect of Pae on tumor metastasis lacks conclusive evidence. Therefore, 
A
0

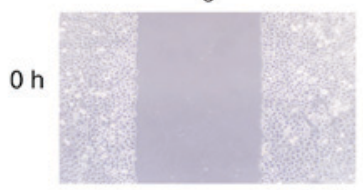

$24 \mathrm{~h}$

$48 \mathrm{~h}$

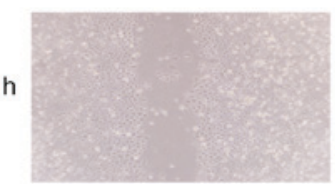

Pae $(\mathrm{mg} / \mathrm{ml})$

0.1
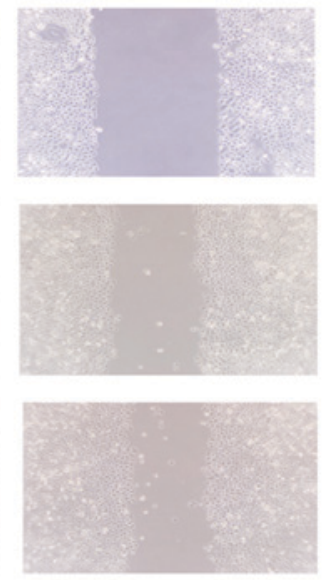

0.2
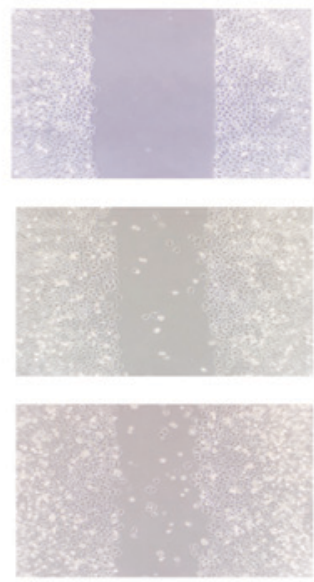

0.4
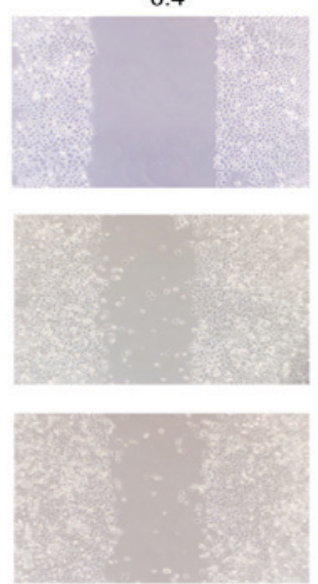

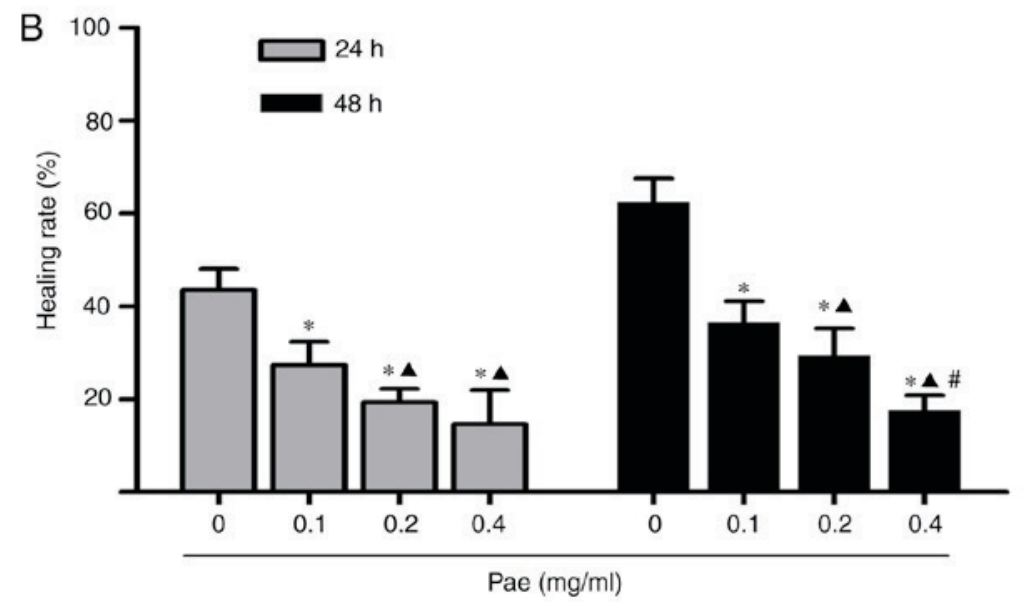

Figure 4. Effect of Pae on the migration of BGC823 cells. (A) Cell scratch-wound areas at 0, 24 and 48 h in each group were observed under an inverted optical microscope (magnification, x200). (B) Quantitative comparison of the wound healing rates at 24 and $48 \mathrm{~h}$ among groups. Data are expressed as the mean \pm standard deviation $(\mathrm{n}=6)$. ${ }^{*} \mathrm{P}<0.05$ vs. $0 ;{ }^{\wedge} \mathrm{P}<0.05$ vs. $0.1 ;{ }^{\#} \mathrm{P}<0.05$ vs. 0.2 . Pae 0 mg/ml, control group; $0.1 \mathrm{mg} / \mathrm{ml}$, low concentration Pae group; $0.2 \mathrm{mg} / \mathrm{ml}$, moderate concentration Pae group; $0.4 \mathrm{mg} / \mathrm{ml}$, high concentration Pae group. Pae, paeonol. $\mathrm{n}$, the number of independent experiments performed.

the present study aimed to investigate the effects of Pae with an emphasis on the invasion and migration of BGC823 gastric cancer cells with strong invasive and metastatic abilities. The results indicated that Pae could inhibit proliferation and induce apoptosis of BGC823 cells, which is in agreement with existing reports (34). Furthermore, the present study presents, to the best of our knowledge, the first evidence of the inhibitory influence of Pae upon invasion and migration of BGC823 cells using cell scratch-wound healing and Transwell invasion assays.

In order to further investigate the possible mechanism of inhibitory activities of Pae on the invasion and migration of gastric cancer cells, the expression levels of MMP-2 and MMP-9 in BGC823 cells were determined after treatment with gradient concentrations of Pae. The results demonstrated that Pae could downregulate the expression levels of MMP-2 and MMP-9 in BGC823 cells in a concentration-dependent manner, which may account for anti-metastatic activities of Pae and represent a potential target mechanism for clinical development of its promising anti-cancer effects. Further studies are needed to investigate the anti-cancer effects of Pae and elucidate its more definite mechanisms of action.
Cell over-proliferation, inhibition of apoptosis and metastasis are basic biological characteristics of malignant tumors. For gastric cancer patients, cancer metastasis is often the main cause leading to disease aggravation and mortality $(35,36)$. Previous research has demonstrated that there are higher MMP-2 and MMP-9 expression levels in gastric tumors, especially in metastatic tumors, than in normal mucosa $(37,38)$. MMPs could be used as diagnostic markers in body fluid, and MMP-2 might be a prognostic marker in ascites of advanced gastric cancer patients with disseminated metastasis (39). Additionally, MMPs have been selected as promising targets for cancer treatment based on their upregulation in malignant tumors and their ability to enhance cancer metastasis (9). Therefore, along with the anti-proliferative and pro-apoptotic effects, the anti-metastatic activities exerted through downregulation of MMPs may support Pae to become a promising therapeutic candidate for the gastric cancer therapy.

\section{Acknowledgements}

The present study was supported by the projects of the Traditional Chinese Medical Science and Technology 
A
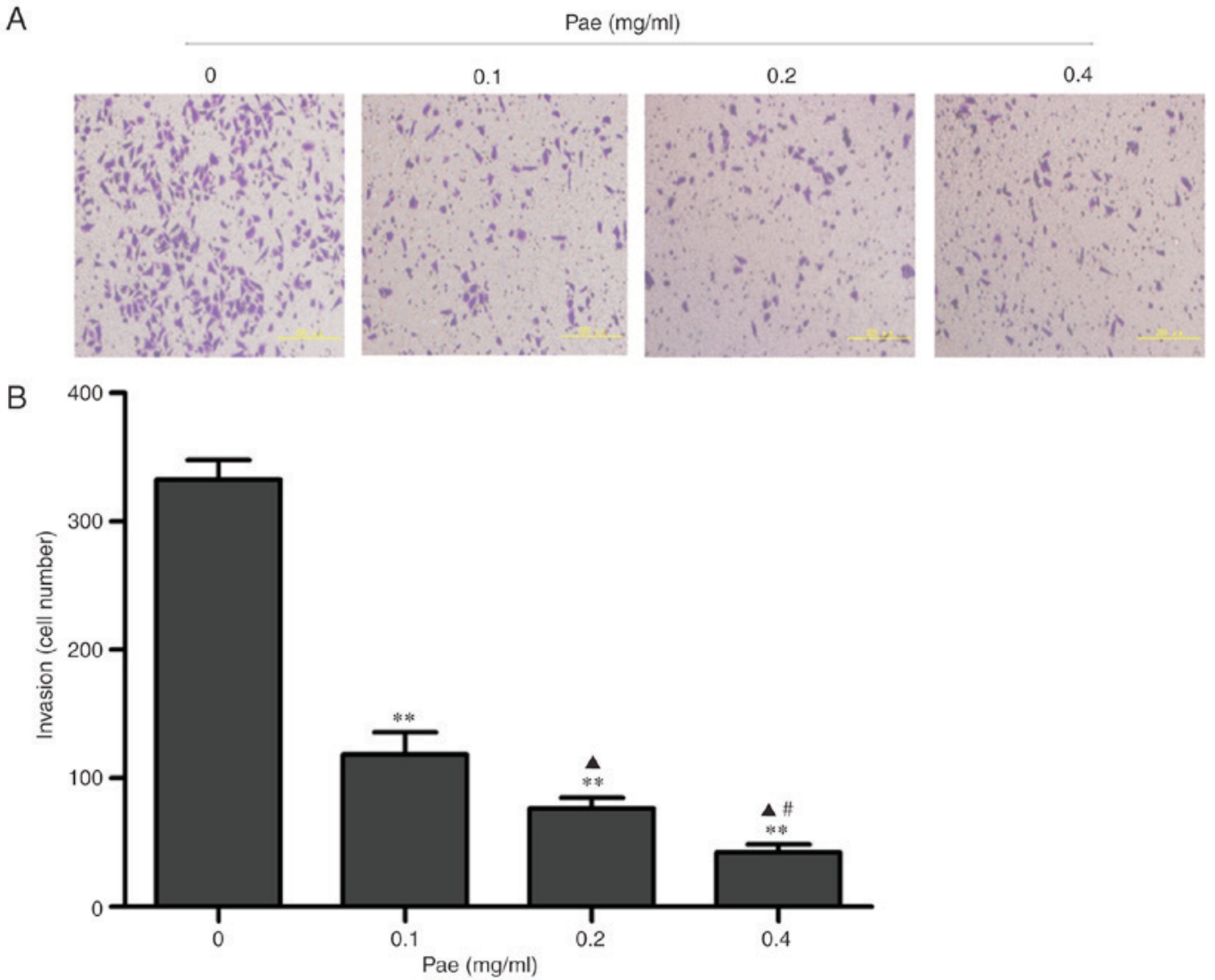

Figure 5. Effect of Pae on the invasion of BGC823 cells after $24 \mathrm{~h}$ of treatment in each group. (A) Stained cells passing the artificial basement membrane were observed under an inverted optical microscope (magnification, x200). (B) Numbers of stained cells were compared among groups. Data are expressed as the mean \pm standard deviation $(\mathrm{n}=3) .{ }^{* *} \mathrm{P}<0.01$ vs. $0 ;{ }^{\wedge} \mathrm{P}<0.05$ vs. $0.1 ;{ }^{*} \mathrm{P}<0.05$ vs. 0.2 . Pae $0 \mathrm{mg} / \mathrm{ml}$, control group; $0.1 \mathrm{mg} / \mathrm{ml}$, low concentration Pae group; $0.2 \mathrm{mg} / \mathrm{ml}$, moderate concentration Pae group; $0.4 \mathrm{mg} / \mathrm{ml}$, high concentration Pae group. Pae, paeonol. $\mathrm{n}$, the number of independent experiments performed.

A

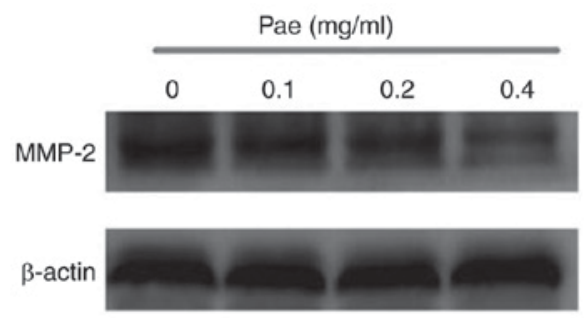

C

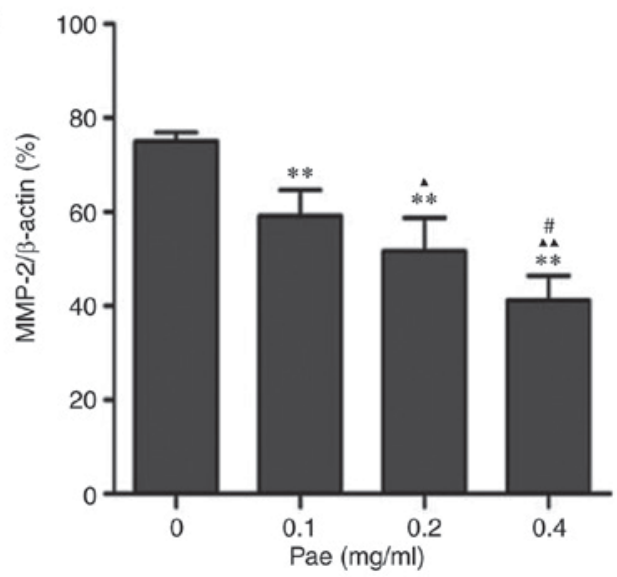

B

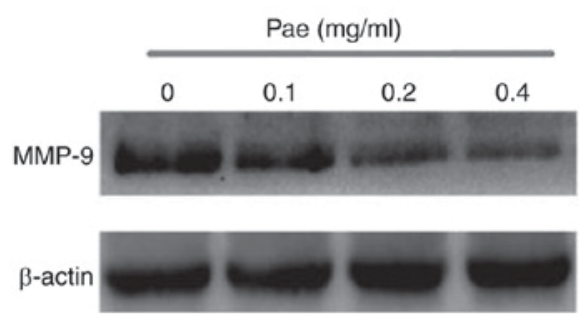

D

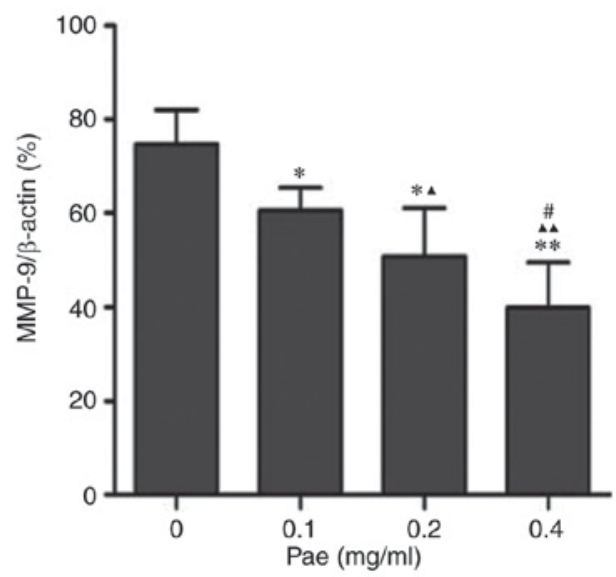

Figure 6. Effect of Pae on the expression levels of MMP-2 and MMP-9 of BGC823 cells at $48 \mathrm{~h}$ of treatment. Representative western blot images of (A) MMP-2 and (B) MMP-9 protein expression levels. Quantitative comparison of the expression levels of (C) MMP-2 and (D) MMP-9 among groups, with $\beta$-actin as a loading control. Data are expressed as the mean \pm standard deviation $(\mathrm{n}=5) .{ }^{*} \mathrm{P}<0.05,{ }^{* * *} \mathrm{P}<0.01$ vs. $0 ;{ }^{\mathbf{\Delta}} \mathrm{P}<0.05,{ }^{\Delta \mathbf{\Delta}} \mathrm{P}<0.01$ vs. $0.1 ;{ }^{*} \mathrm{P}<0.05$ vs. 0.2 . Pae $0 \mathrm{mg} / \mathrm{ml}$, control group; $0.1 \mathrm{mg} / \mathrm{ml}$, low concentration Pae group; $0.2 \mathrm{mg} / \mathrm{ml}$, moderate concentration Pae group; $0.4 \mathrm{mg} / \mathrm{ml}$, high concentration Pae group. MMP, matrix metalloproteinase; Pae, paeonol. $\mathrm{n}$, the number of independent experiments performed. 
Development Program in Shandong Province (grant no. 2013-27) and the Fundamental Research Funds of Shandong University (grant no. 2014QLKY07).

\section{References}

1. de Martel C, Forman D and Plummer M: Gastric cancer: Epidemiology and risk factors. Gastroenterol Clin North Am 42: 219-240, 2013

2. Ferlay J, Soerjomataram I, Dikshit R, Eser S, Mathers C, Rebelo M, Parkin DM, Forman D and Bray F: Cancer incidence and mortality worldwide: Sources, methods and major patterns in GLOBOCAN 2012. Int J Cancer 136: E359-E386, 2015.

3. Jemal A, Bray F, Center MM, Ferlay J, Ward E and Forman D: Global cancer statistics. CA Cancer J Clin 61: 69-90, 2011.

4. Ohtsu A, Yoshida S and Saijo N: Disparities in gastric cancer chemotherapy between the East and West. J Clin Oneol 24: 2188-2196, 2006.

5. de Vries AC and Kuipers EJ: Epidemiology of premalignant gastric lesions: Implications for the development of screening and surveillance strategies. Helicobacter 12 (Suppl 2): S22-S31, 2007.

6. Kalluri R: Basement membranes: Structure, assembly and role in tumour angiogenesis. Nat Rev Cancer 3: 422-433, 2003.

7. Liotta LA and Kohn EC: The microenvironment of the tumour-host interface. Nature 411: 375-379, 2001.

8. Kessenbrock K, Plaks V and Werb Z: Matrix metalloproteinases: Regulators of the tumor microenvironment. Cell 141: 52-67,2010

9. Hua H, Li M, Luo T, Yin Y and Jiang Y: Matrix metalloproteinases in tumorigenesis: An evolving paradigm. Cell Mol Life Sci 68: 3853-3868, 2011

10. Curran S and Morray GI: Matrix metalloproteitases in tumour invasion and metastasis. J Pathol 189: 300-308, 1999.

11. Zeng ZS, Cohen AM and Guillem JG: Loss of basement membrane type IV collagen is associated with increased expression of metalloproteinases 2 and 9 (MMP-2 and MMP-9) during human colorectal tumorigenesis. Carcinogenesis 20: 749-755, 1999.

12. Heikinheimo K and Salo T: Expression of basement membrane type IV collagen and type IV collagenases (MMP-2 and MMP-9) in human fetal teeth. J Dent Res 74: 1226-1234, 1995.

13. Roach DM, Fitridge RA, Laws PE, Millard SH, Varelias A and Cowled PA: Up-regulation of MMP-2 and MMP-9 leads to degradation of type IV collagen during skeletal muscle reperfusion injury; protection by the MMP inhibitor, doxycycline. Eur J Vasc Endovasc Surg 23: 260-269, 2002

14. Zhao Y, Zhou FL, Li WP, Wang J and Wang LJ: Slit2-Robol signaling promotes the adhesion, invasion and migration of tongue carcinoma cells via upregulating matrix metalloproteinases 2 and 9 and downregulating E-cadherin. Mol Med Rep 14 1901-1906, 2016.

15. Liu C: Pathological and prognostic significance of matrix metalloproteinase-2 expression in ovarian cancer: A meta-analysis. Clin Exp Med 16: 375-382, 2016

16. Pazzaglia L, Ponticelli F, Magagnoli G, Magagnoli G, Gamberi G, Ragazzini P, Balladelli A, Picci P and Benassi M: Activation of metalloproteinases- 2 and -9 by interleukin-1alpha in S100A4-positive liposarcoma cell line: Correlation with cel invasiveness. Anticancer Res 24: 967-972, 2004.

17. Hwang TL, Changchien TT, Wang CC and Wu CM: Claudin-4 expression in gastric cancer cells enhances the invasion and is associated with the increased level of matrix metalloproteinase-2 and -9 expression. Oncol Lett 8: 1367-1371, 2014.

18. Chen SJ, Yao XD, Peng BO, Xu YF, Wang GC, Huang J, Liu M and Zheng JH: Epigallocatechin-3-gallate inhibits migration and invasion of human renal carcinoma cells by downregulating matrix metalloproteinase-2 and matrix metalloproteinase-9. Exp Ther Med 11: 1243-1248, 2016

19. Sun W, Liu DB, Li WW, Zhang LL, Long GX, Wang JF, Mei Q and $\mathrm{Hu}$ GQ: Interleukin-6 promotes the migration and invasion of nasopharyngeal carcinoma cell lines and upregulates the expression of MMP-2 and MMP-9. Int J Oncol 44: 1551-1560, 2014.
20. Lee KR, Lee JS, Song JE, Ha SJ and Hong EK: Inonotus obliquus-derived polysaccharide inhibits the migration and invasion of human non-small cell lung carcinoma cells via suppression of MMP-2 and MMP-9. Int J Oncol 45: 2533-2540, 2014.

21. Riley CM and Ren TC: Simple method for the determination of paeonol in human and rabbit plasma by high-performance liquid chromatography using solid-phase extraction and ultraviolet detection. J Chromatogr 489: 432-437, 1989.

22. Jiang SP and Chen YX: Advances in the research and its clinical application of Cynanchum paniculatum (Bge.) Kitag. Zhongguo Zhong Yao Za Zhi 19: 311-314, 1994 (In Chinese).

23. Anh Hle T, Cuc NT, Tai BH, Yen PH, Nhiem NX, Thao do T, Nam NH, Van Minh C, Van Kiem P and Kim YH: Synthesis of chromonylthiazolidines and their cytotoxicity to human cancer cell lines. Molecules 20: 1151-1160, 2015.

24. Xu SP, Sun GP, Shen YX, Wei W, Peng WR and Wang H: Antiproliferation and apoptosis induction of paeonol in HepG2 cells. World J Gastroenterol 13: 250-256, 2007.

25. Li M, Tan SY and Wang XF: Paeonol exerts an anticancer effect on human colorectal cancer cells through inhibition of $\mathrm{PGE}_{2}$ synthesis and COX-2 expression. Oncol Rep 32: 2845-2853, 2014.

26. Yin J, Wu N, Zeng F, Cheng C, Kang K and Yang H: Paeonol induces apoptosis in human ovarian cancer cells. Acta Histochem 115: 835-839, 2013.

27. Horng CT, Shieh PC, Tan TW, Yang WH and Tang CH: Paeonol suppresses chondrosarcoma metastasis through up-regulation of miR-141 by modulating PKC $\delta$ and c-Src signaling pathway. Int J Mol Sci 15: 11760-11772, 2014

28. Kim SA, Lee HJ, Ahn KS, Lee HJ, Lee EO, Ahn KS, Choi SH, Jung SJ, Kim JY, Baek N and Kim SH: Paeonol exerts anti-angiogenic and anti-metastatic activities through downmodulation of Akt activation and inactivation of matrix metalloproteinases. Biol Pharm Bull 32: 1142-1147, 2009.

29. Katakai M, Akamaru T and Tani T: An analysis of appearance frequency of formulations and crude drugs in Jin-Kui-Yao-Lue. Yakushigaku Zasshi 38: 1-10, 2003 (In Japanese).

30. Fan L, Song B, Sun G, Ma T, Zhong F and Wei W: Endoplasmic reticulum stress-induced resistance to doxorubicin is reversed by paeonol treatment in human hepatocellular carcinoma cells. PLoS One 8: e62627, 2013.

31. Chou TC: Anti-inflammatory and analgesic effects of paeonol in carrageenan-evoked thermal hyperalgesia. Br J Pharmacol 139: 1146-1152, 2003

32. Xu SP, Sun GP, Shen YX, Peng WR, Wang H and Wei W: Synergistic effect of combining paeonol and cisplatin on apoptotic induction of human hepatoma cell lines. Acta Pharmacol Sin 28: 869-878, 2007

33. Cai J, Chen S, Zhang W, Hu S, Lu J, Xing J and Dong Y: Paeonol reverses paclitaxel resistance in human breast cancer cells by regulating the expression of transgelin 2. Phytomedicine 21: 984-991, 2014.

34. Li N, Fan LL, Sun GP, Wan XA, Wang ZG, Wu Q and Wang H: Paeonol inhibits tumor growth in gastric cancer in vitro and in vivo. World J Gastroenterol 16: 4483-4490, 2010.

35. Hohenberger P and Gretschel S: Gastric cancer. Lancet 362: 305-315, 2003.

36. Krejs GJ: Gastric cancer: Epidemiology and risk factors. Dig Dis 28: 600-603, 2010.

37. Parsons SL, Watson SA, Collins HM, Griffin NR, Clarke PA and Steele RJ: Gelatinase (MMP-2 and -9) expression in gastrointestinal malignancy. Br J Cancer 78: 1495-1502, 1998.

38. Lim SC: Expression of matrix metalloproteinases and its inhibitor in gastric adenocarcinoma. Cancer Res Treat 33: 199-206, 2001.

39. Noh S, Jung JJ, Jung M, Kim TS, Park CH, Lim SJ, Jeung HC, Cheol H, Chung HC and Rha SY: MMP-2 as a putative biomarker for carcinomatosis in gastric cancer. Hepatogastroenterology 58: 2015-2019, 2011 